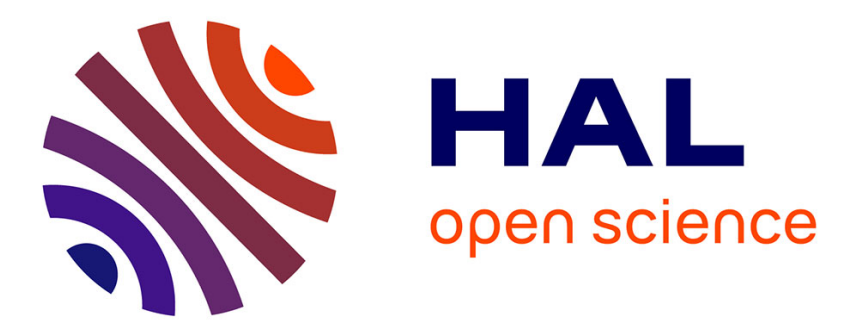

\title{
Wind tunnel study of ammonia transfer from a manure pit fitted with a dairy cattle slatted floor
}

Merlijn de Paepe, Jan G. Pieters, Luciano Barreto Mendes, Stephanie van Weyenberg, Bart Merci, Peter Demeyer

\section{- To cite this version:}

Merlijn de Paepe, Jan G. Pieters, Luciano Barreto Mendes, Stephanie van Weyenberg, Bart Merci, et al.. Wind tunnel study of ammonia transfer from a manure pit fitted with a dairy cattle slatted floor. Environmental Technology, 2016, 37 (2), pp.202-215. 10.1080/09593330.2015.1066449 . hal01606248

\section{HAL Id: hal-01606248 \\ https://hal.science/hal-01606248}

Submitted on 27 May 2020

HAL is a multi-disciplinary open access archive for the deposit and dissemination of scientific research documents, whether they are published or not. The documents may come from teaching and research institutions in France or abroad, or from public or private research centers.
L'archive ouverte pluridisciplinaire HAL, est destinée au dépôt et à la diffusion de documents scientifiques de niveau recherche, publiés ou non, émanant des établissements d'enseignement et de recherche français ou étrangers, des laboratoires publics ou privés.

\section{다(1)(2)}

Distributed under a Creative Commons Attribution - ShareAlike| 4.0 International 
This article was downloaded by: [IIASA]

On: 03 August 2015, At: 08:59

Publisher: Taylor \& Francis

Informa Ltd Registered in England and Wales Registered Number: 1072954 Registered office: 5 Howick Place, London, SW1P IWG

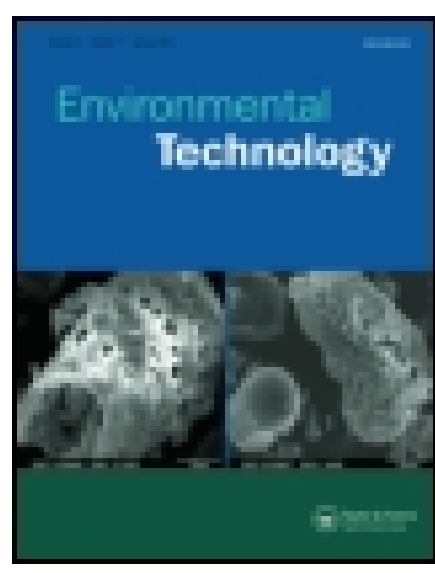

CrossMark

\title{
Environmental Technology
}

Publication details, including instructions for authors and subscription information: http:// www. tandfonline.com/loi/tent20

\section{Wind tunnel study of ammonia transfer from a manure pit fitted with a dairy cattle slatted floor}

\author{
Merlijn De Paepe ${ }^{a}$, J an G. Pieters ${ }^{b}$, Luciano B. Mendes ${ }^{a}$, Stephanie Van Weyenberg ${ }^{a}$, Bart \\ Merci $^{\mathrm{c}} \&$ Peter Demeyer ${ }^{\mathrm{a}}$ \\ ${ }^{a}$ Technology and Food Science Unit (T\&V), Institute of Agricultural and Fisheries Research \\ (ILVO), Burg Van Gansberghelaan 115 Box 1, 9820 Merelbeke, Belgium \\ ${ }^{\mathrm{b}}$ Department of Biosystems Engineering, Ghent University, Coupure Links 653, B-9000 \\ Ghent, Belgium \\ ${ }^{\mathrm{C}}$ Deptartment of Flow, Heat and Combustion Mechanics, Ghent University, EA03 Sint- \\ Pietersnieuwstraat 41, B-9000 Ghent, Belgium \\ Accepted author version posted online: 29 J un 2015. Published online: $29 \mathrm{~J} \mathrm{ul} 2015$.
}

To cite this article: Merlijn De Paepe, J an G. Pieters, Luciano B. Mendes, Stephanie Van Weyenberg, Bart Merci \& Peter Demeyer (2015): Wind tunnel study of ammonia transfer from a manure pit fitted with a dairy cattle slatted floor, Environmental Technology, DOI: 10.1080/ 09593330.2015.1066449

To link to this article: http:// dx. doi. org/ 10.1080/09593330.2015.1066449

\section{PLEASE SCROLL DOWN FOR ARTICLE}

Taylor \& Francis makes every effort to ensure the accuracy of all the information (the "Content") contained in the publications on our platform. However, Taylor \& Francis, our agents, and our licensors make no representations or warranties whatsoever as to the accuracy, completeness, or suitability for any purpose of the Content. Any opinions and views expressed in this publication are the opinions and views of the authors, and are not the views of or endorsed by Taylor \& Francis. The accuracy of the Content should not be relied upon and should be independently verified with primary sources of information. Taylor and Francis shall not be liable for any losses, actions, claims, proceedings, demands, costs, expenses, damages, and other liabilities whatsoever or howsoever caused arising directly or indirectly in connection with, in relation to or arising out of the use of the Content.

This article may be used for research, teaching, and private study purposes. Any substantial or systematic reproduction, redistribution, reselling, loan, sub-licensing, systematic supply, or distribution in any form to anyone is expressly forbidden. Terms $\&$ Conditions of access and use can be found at http:// www.tandfonline.com/page/terms-and-conditions 


\title{
Wind tunnel study of ammonia transfer from a manure pit fitted with a dairy cattle slatted floor
}

\author{
Merlijn De Paepe ${ }^{\mathrm{a}}$, Jan G. Pieters ${ }^{\mathrm{b}}$, Luciano B. Mendes ${ }^{\mathrm{a}}$ (D), Stephanie Van Weyenberg ${ }^{\mathrm{a}}$, Bart Merci ${ }^{\mathrm{c}}$ and Peter Demeyer ${ }^{\mathrm{a} *}$ \\ ${ }^{a}$ Technology and Food Science Unit (T\&V), Institute of Agricultural and Fisheries Research (ILVO), Burg Van Gansberghelaan 115 Box \\ 1, 9820 Merelbeke, Belgium; ${ }^{b}$ Department of Biosystems Engineering, Ghent University, Coupure Links 653, B-9000 Ghent, Belgium; \\ ${ }^{c}$ Deptartment of Flow, Heat and Combustion Mechanics, Ghent University, EA03 Sint-Pietersnieuwstraat 41, B-9000 Ghent, Belgium
}

\author{
(Received 3 April 2015; accepted 22 June 2015)
}

\begin{abstract}
In dairy cattle systems, most of the feces and urine go to the pit. At the manure pit level, mass transfer of $\mathrm{NH}_{3}\left(k_{\mathrm{NH}_{3}}\right)$ has many factors, but practical difficulties hamper a controlled field evaluation. In this study, we propose a methodology for the determination of an alternative, more practical, pit transfer coefficient of $\mathrm{NH}_{3}(P T C)$, and compare it with $k_{\mathrm{NH}_{3}}$ determined from other scientific studies. The aims of this research study were: (1) to develop a wind tunnel set-up which mimics air flow patterns between the slats and above a clean section of a slatted floor section, featuring an aqueous $\mathrm{NH}_{3}$-emitting solution; and (2) to assess how air velocity, turbulence intensity, $\mathrm{NH}_{3}$ concentration $\left(\left[\mathrm{NH}_{3}\right]\right)$ and $P T C$ are influenced by inlet airflow ventilation rate $(V R)$ forced deflection of the air above the slats into the manure pit through varying the deflection angle $(D A)$ of a deflection panel and varying pit headspace height $(H H)$. Main conclusions were: (1) the calculated PTC values presented a good fit to the power function of the air speed near the slats $(u)(p<.001)$ while the average PTC $(0.0039$ $\mathrm{m} \mathrm{s}^{-1}$ ) was comparable to $k_{\mathrm{NH}_{3}}$ values obtained from other studies, by remaining within the range of average values of $0.0015-0.0043 \mathrm{~m} \mathrm{~s}^{-1}$; (2) $V R$ and $D A$ significantly impacted $\left[\mathrm{NH}_{3}\right]$ profiles and PTC $(p<.001)$ and (3) changing slurry pit from 0.10 to $0.90 \mathrm{~m} \mathrm{HH}$ did not significantly impact $\left[\mathrm{NH}_{3}\right]$ or $P T C$ ( $p=.756$ and $p=.854$, respectively).
\end{abstract}
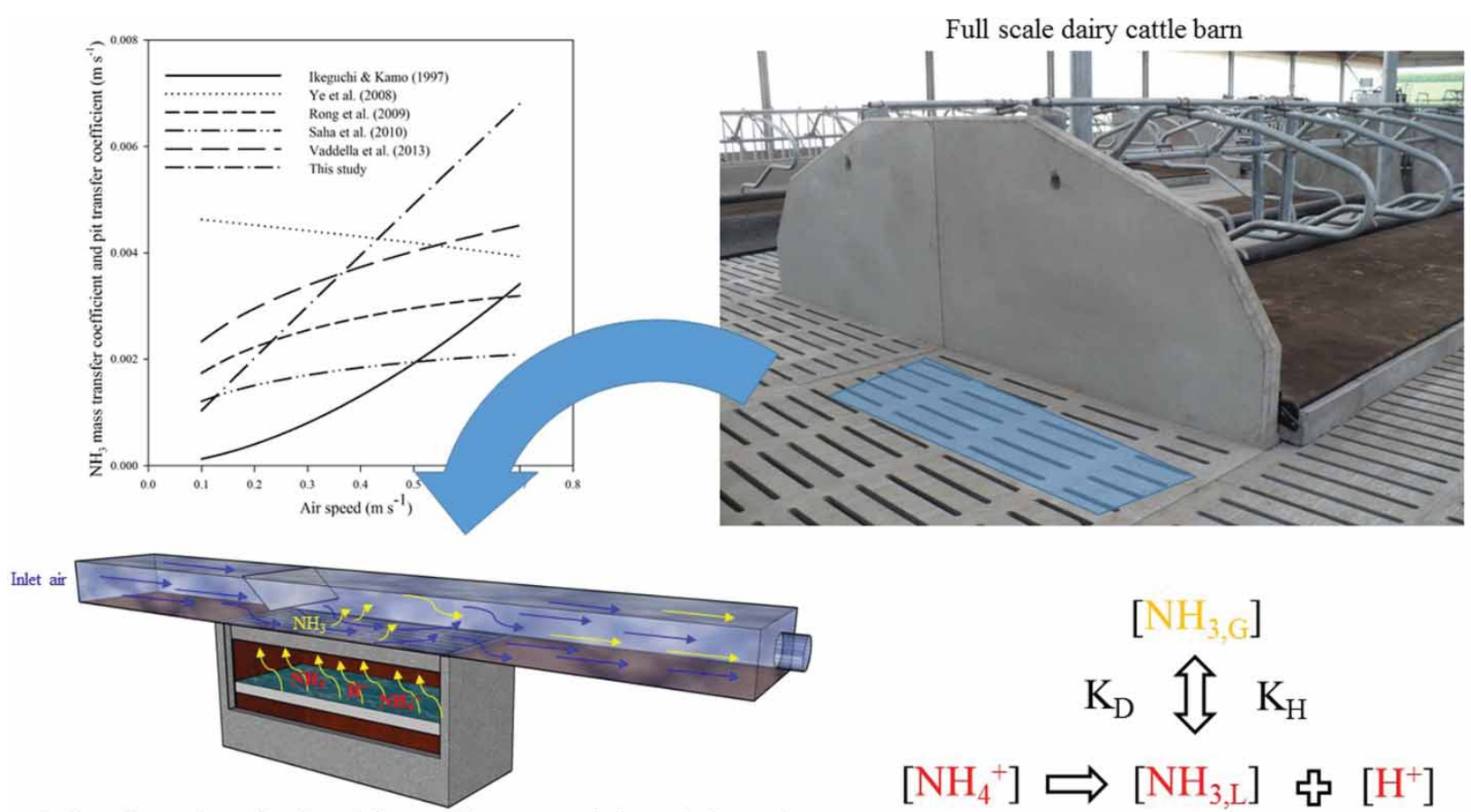

Full scale section of a slatted floor with manure pit in a windtunnel

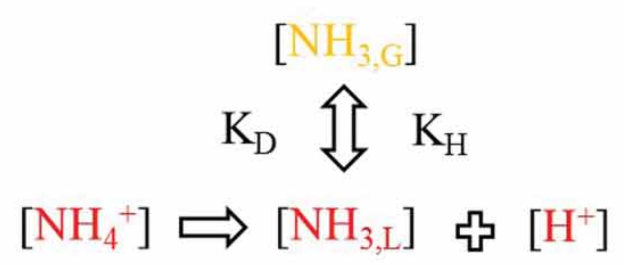

Keywords: ammonia-emitting solution; pit headspace height; barn ventilation rate; automatic solution $\mathrm{pH}$ control; flow patterns

*Corresponding author. Email: peter.demeyer@ilvo.vlaanderen.be 


\section{Introduction}

The gas ammonia $\left(\mathrm{NH}_{3}\right)$ is a major cause of indoor air pollution in livestock systems, affecting animal and human health [1] and once released into the environment, it contributes to eutrophication and acidification of ecosystems.[2-5] Hence, as from 2001, European Union's National Emission Ceiling (NEC) Directive imposed the maximum allowed $\mathrm{NH}_{3}$ emission levels to be reached by each country member. Since then, many research studies have been developed with the attempt to test mitigation strategies in order to abate $\mathrm{NH}_{3}$ emissions from production systems of the main livestock categories, including cattle barns.

Cattle farms are known for producing large amounts of excrements and for significantly emitting $\mathrm{NH}_{3}$ when compared to other livestock categories.[6-8] The majority of cattle houses in Belgium and Northern Europe feature slatted floors on top of a manure pit. In these systems, a considerable percentage of the total excreted nitrogen is transformed still on top of the slatted floor, namely into $\mathrm{NH}_{3}$ through an enzymatic reaction of urease (abundantly present in feces) on urea (in the urine).[9] Nevertheless, most of the excrements pass through the slats into the pit, where under certain conditions $\mathrm{NH}_{3}$ is released to the air through enzymatic degradation and bacteriological decomposition.[10-13]

The transfer of $\mathrm{NH}_{3}$ from the slatted floor surface in livestock systems has been widely studied,[14-19] while the factors related to $\mathrm{NH}_{3}$ transfer from the pit are not yet fully understood. There are many practical difficulties concerning field determination of the contribution of the manure pit to total emissions. For instance, the harsh environmental conditions under the floor make it a challenging place to monitor. Attempting to reproduce and study emissions from the manure pit in laboratory conditions may be advantageous.

The $\mathrm{NH}_{3}$ mass transfer coefficient $\left(k_{\mathrm{NH}_{3}}\right)$ is inversely proportional to the concentration gradient $\left(\Delta\left[\mathrm{NH}_{3}\right]=\right.$ $\left.\left[\mathrm{NH}_{3}\right]_{i}-\left[\mathrm{NH}_{3}\right]_{\infty}\right)$, which is defined by the difference between the concentration measured at the fluid interface $\left(\left[\mathrm{NH}_{3}\right]_{i}\right)$ and at a certain distance from the source $\left(\left[\mathrm{NH}_{3}\right]_{\infty}\right)$. [20] While making measurements of $\left[\mathrm{NH}_{3}\right]_{i}$ in the lab is feasible with free emitting surfaces, the presence of the slats in practical situations might make it a cumbersome task. Still, the determination of a manure pit transfer coefficient (PTC) with the same logistic model used to estimate $k_{\mathrm{NH}_{3}}$, but considering $\left[\mathrm{NH}_{3}\right]_{o}$ as the $\mathrm{NH}_{3}$ concentration measured between the slats, may lead to valuable information to characterize emissions from full-scale barns, if $P T C$ values compared well to $k_{\mathrm{NH}_{3}}$.

It is well known that $\mathrm{NH}_{3}$ volatilization from manure is dependent on variables such as nitrogen content, temperature $(T), p H$ and air flow properties near the emitting surface.[15,21,22] The latter are of crucial importance in triggering the $\mathrm{NH}_{3}$ release process,[17] because they allow for the convective transport of freshly volatilized molecules upwards the manure pit and the barn, a mechanism that repeats itself for as long as the conditions are favourable.[23-26]

Ye et al. [27] and Ye et al. [28] reported laboratory studies carried out to evaluate the effect of air velocity $(u)$, turbulence intensity $(T I), p H$, slats opening size and headspace height $(H H)$ on $\mathrm{NH}_{3}$ emissions from a scale pig house model with an aqueous solution mimicking the manure. In a later study, Ye et al. [29] monitored several climate and design variables along with $\mathrm{NH}_{3}$ emissions from pigs housed in a full-size experimental room. Those authors found that the factors that explained most of the variability of $\mathrm{NH}_{3}$ emissions from the pigs were ventilation rate $(V R)$, floor system, manure temperature, $H H$ and the presence of a manure pit curtain. Although these reduced and full-size scale studies explained influencing factors on $\mathrm{NH}_{3}$ emission rates from pig houses, their outcomes might not be transferable to dairy cattle housing systems with slatted floor, due to the obvious inherent differences between systems such as animal category and thus manure properties, barn design and the overall system management.

Dairy cattle houses are mostly naturally ventilated, $[7,30]$ and modern design systems account for relatively large side openings which allow for high air exchange rates that will likely lead to higher air velocities near the slats, potentially having a stronger impact on the flow properties in the manure pit headspace than in mechanically ventilated barns. Due to regulations set by European and national laws in Belgium,[31] field applications of manure are only allowed between February and October, meaning that for half of the year the manure usually has to remain in the pit, which will cause it to be nearly at maximum capacity for a couple of months. The headspace volume of the manure pit has been found to influence $k_{\mathrm{NH}_{3}}$, because at lower $H H$ values, the boundary layer [32] at the manure liquid surface is more likely to be affected by the flow patterns near the slats. However, a controlled study including the combined effect of ventilation patterns, that is, air velocity $(u)$ and $T I$ near the slats with effects of $H H$ that are applicable to dairy cattle systems is meager in the current literature.

Therefore, the aim of this study was to develop a wind tunnel set-up which mimics airflow patterns between the openings and in the first centimeters above a clean section of a slatted floor typically found in dairy cattle barns, equipped with an aqueous $\mathrm{NH}_{3}$-emitting surface that resembles manure pit conditions. Specific objectives were: (a) to assess how $u, T I$ and $\left[\mathrm{NH}_{3}\right]$ are influenced by different $V R$ values, by deflecting the air flow in the first centimeters above the slats and by varying $H H$ and (b) to calculate $P T C$ values from the wind tunnel set-up and compare it to $k_{\mathrm{NH}_{3}}$ values from other studies, and assess $P T C$ dependence on changing $V R$, deflection angle $(D A)$ and $H H$. 


\section{Materials and methods}

In order to achieve the objectives of the study, one section of a slatted floor typically found in dairy cow barns was placed in the test section of a wind tunnel specially built for this purpose. Under the slatted floor, the manure pit was represented by a container holding an automatically controlled $\mathrm{NH}_{3}$-emitting solution. A detailed description of the wind tunnel with slatted floor and pit construction, automatic $\mathrm{NH}_{3}$-emitting solution preparation, experimental procedures and data analysis is provided below.

\section{Description of the wind tunnel with manure pit model and $\mathrm{NH}_{3}$ release control set-up}

An $8.00 \mathrm{~m}$ Long $\times 1.15 \mathrm{~m}$ Wide $\times 0.50 \mathrm{~m} \operatorname{High}(L \times W$ $\times H$ ) wind tunnel was constructed inside an environmentally semi-controlled laboratory (central ventilation and heating system for control of temperature and $V R$, Figure 1). The wind tunnel consisted of a stainless steel frame, with concrete floor and walls, and windows of Plexiglas ${ }^{\circledR}$. Negative pressure conditions were created inside the wind tunnel with a suction fan (Fancom BV, model IF35, Panningen, the Netherlands) placed at the outlet side. The fan air flow rate was controlled and varied between 0 and $1350 \mathrm{~m}^{3} \mathrm{~h}^{-1}$, resulting in inlet air velocities $\left(u_{\text {inlet }}\right)$ in the range of $0-0.65 \mathrm{~m} \mathrm{~s}^{-1}$. The test section of the wind tunnel was located $2.5 \mathrm{~m}$ from both extremities, and had dimensions of $3.00 \mathrm{~m} \mathrm{~L} \times 1.00 \mathrm{~m} \mathrm{~W} \times 0.500 \mathrm{~m} \mathrm{H}$. The floor of the test section consisted of full-scale concrete slats, typically applied in dairy cow barns, with dimensions of $3.00 \mathrm{~m} L \times 1.00 \mathrm{~m} W \times 0.18 \mathrm{~m}$ Depth $(D)$, containing a total of 30 slits, each measuring $0.49 \mathrm{~m} L \times 0.04$ $\mathrm{m} W$, thus yielding an opening porosity of $20 \%$. The space under the slats had dimensions of $2.66 \mathrm{~m} L \times 1$ $\mathrm{m} W \times 1.38 \mathrm{~m} D$. The manure pit had a custom-built stainless steel container $(2.65 \mathrm{~m} L \times 1.00 \mathrm{~m} \mathrm{~W} \times 0.19 \mathrm{~m}$ $H$ ) mounted on a hydraulic lift table (BD Lift \& Container International AB, Klippan, Sweden), which allowed for different pit $H H$ ranging from 0.10 to $0.90 \mathrm{~m}$. To ensure air tightness around the container, an inflatable tube was installed along its edges, closing all gaps near the pit walls.

In order to divert the air flow entering the test section, a deflector panel was additionally installed inside the wind tunnel at $0.43 \mathrm{~m}$ from the inlet side of the test section, that is, above the first set of floor slits. The deflector consisted of a $0.005 \mathrm{~m}$ thick polycarbonate shield spanning the wind tunnel cross-sectional area. A rotating axis placed at the top of the deflector allowed for manual positioning at any angle between $0^{\circ}$ and $90^{\circ}$. The setting of $0^{\circ}$ resulted in no change in airflow direction, since this was the horizontal position of the deflector, while $90^{\circ}$ implied a complete downward airflow deviation towards the frontal set of floor slits.

The stainless steel container in the pit was filled with $0.225 \mathrm{~m}^{3}$ of a standard $10^{8} \mathrm{mg} \mathrm{m}^{-3}$ ammonium chloride $\left(\mathrm{NH}_{4} \mathrm{Cl}\right)$ solution, prepared by dissolving $\mathrm{NH}_{4} \mathrm{Cl}$ in tap water, yielding a total ammonia nitrogen (TAN) concentration of $33.7 \mathrm{mg} \mathrm{m}^{-3}$. This relatively high concentration was chosen to avoid the depletion of the $\mathrm{NH}_{3}$-emitting source during the course of the experiments.

To allow for a stable level of $\mathrm{NH}_{3}$ volatilization from the liquid phase, the $p H$ of the solution was controlled by constant circulation of $\mathrm{NH}_{4} \mathrm{Cl}$ solution from and to the container, at a rate of approximately $5 \times 10^{-4} \mathrm{~m}^{3} \mathrm{~s}^{-1}$, through a custom-built pumping system. The $\mathrm{NH}_{4} \mathrm{Cl}$ solution $p H$ was maintained at a set-point of 8.00 by dosing with the buffer solution, which yielded an $\mathrm{NH}_{3} / \mathrm{NH}_{4}{ }^{+}$ratio of 20\%.[33] The buffer solution consisted of a 1:1 solution of $\mathrm{Na}_{2} \mathrm{CO}_{3}$ and $\mathrm{NaHCO}_{3}$, leading to a buffer concentration of $184 \mathrm{mg} \mathrm{m}^{-3}$, which was stored in a separate container. The $p H$ of the $\mathrm{NH}_{4} \mathrm{Cl}$ solution was monitored with an electrode-type sensor (model HI 1006-32, Hanna Instruments, $0.1 \mathrm{~Hz}$ measuring frequency, 0.01 precision) fitted to the circulation system. When the $p H$ of the $\mathrm{NH}_{4} \mathrm{Cl}$ solution dropped below the set-point value, a solenoid valve (type $\mathrm{pH}$ 500, Hanna Instruments, Temse, Belgium) dosed buffer solution into the circulatory system in order to keep the $p H$ constant (Figure 2). The temperature of the $\mathrm{NH}_{4} \mathrm{Cl}$ solution $\left(T_{\mathrm{sol}}\right)$ was measured with a resistance temperature sensor (RTD type, Jumbo GmbH \& Co.

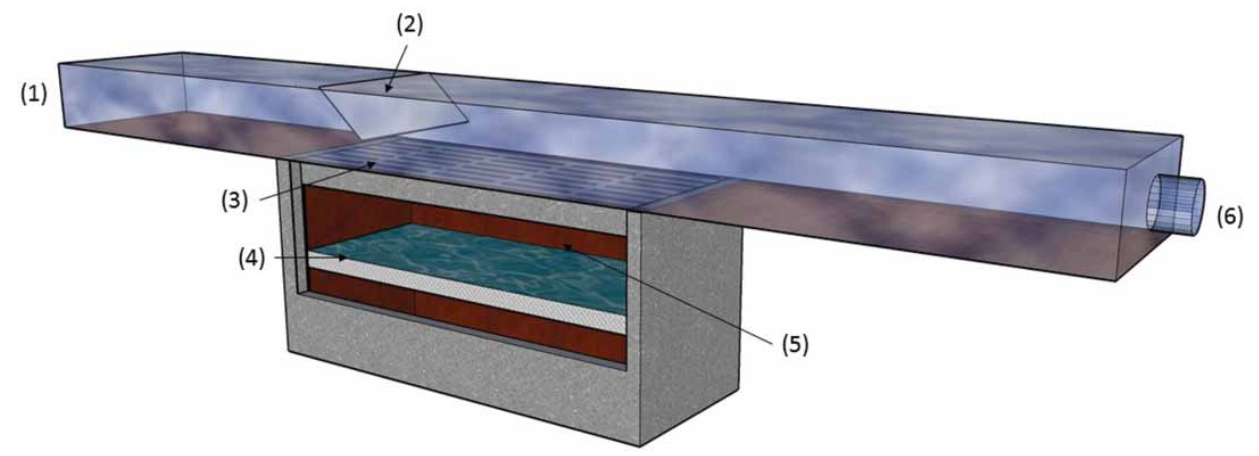

Figure 1. Representation of the wind tunnel set-up. 1, inlet; 2, wind deflector panel; 3, slatted floor; 4, buffered $\mathrm{NH}_{4} \mathrm{Cl}$ solution container; 5 , headspace volume; 6 , exhaust. 


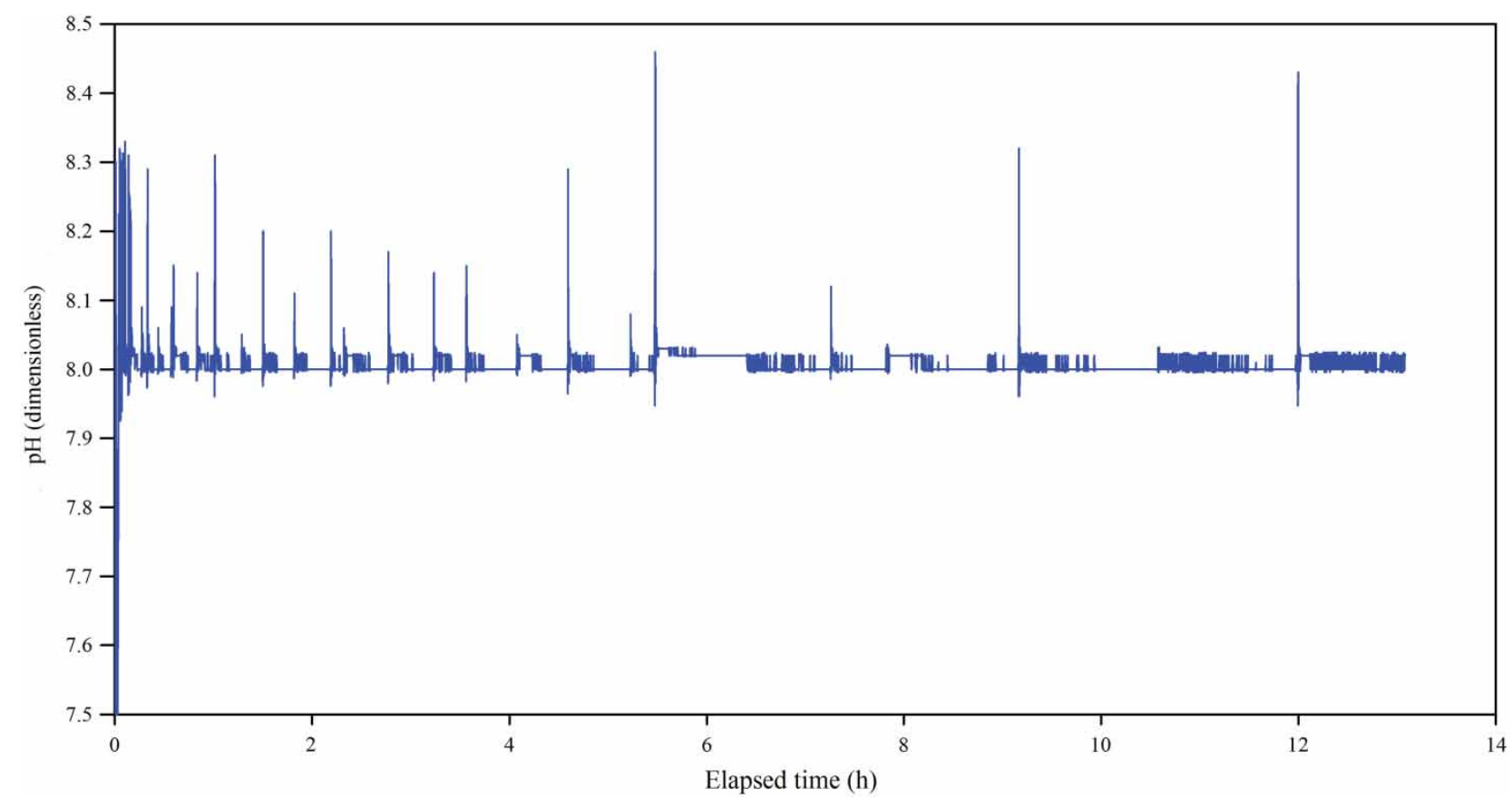

Figure 2. Snapshot of aqueous solution $p H 15$ hours prior to the start-up of an experimental section. The peaks above 8.1 denote momentary dosage events with buffer solution.

$\mathrm{KG}$, Fulda, Germany, $0.017 \mathrm{~Hz}$ sampling frequency, $0.1^{\circ} \mathrm{C}$ precision). Aqueous solution $\mathrm{pH}$ and $T_{\text {sol }}$ were recorded by a data logger (Squirrel type 2040, Grant Instruments, Cambridge, UK).

\section{Monitored variables and system check-up procedures}

The monitoring of $u$ was performed with unidirectional hot-film anemometers (Model EE66, E + E Elektronic, Engerwitsdorf, Germany, $0.017 \mathrm{~Hz}$ sampling frequency, $0.01 \mathrm{~m} \mathrm{~s}^{-1}$ precision) at two different heights. Between slats and above slats in the middle height of the wind tunnel $(0.25 \mathrm{~m})$, at two positions ( $1 \mathrm{~m}$ apart from each other) along the length of the wind tunnel experimental section, totalizing four different points in space. One additional anemometer was installed upstream the deflector panel, at $0.25 \mathrm{~m}$ from the slats for monitoring the undisturbed inlet air velocity $\left(u_{\text {inlet }}\right.$, Figure 3).

At each position where air velocity measurements were taken, $T I$ values were calculated with Equation (1):

$$
T I=S D_{u} / u_{\text {avg }}
$$

where $T I$ is the turbulence intensity (dimensionless); $S D_{\mathrm{u}}$ is the standard deviation of the air velocity measured at a certain point over the time length of measurements (90 min, $\mathrm{m} \mathrm{s}^{-1}$ ) and $u_{\text {avg }}$ is the mean air velocity at a certain point over the time length of measurements $\left(90 \mathrm{~min}, \mathrm{~m} \mathrm{~s}^{-1}\right)$.

Concentrations of $\mathrm{NH}_{3}$ were monitored with a photoacoustic analyzer (model INNOVA 1314, AirTech Instruments, Ballerup, Denmark, $0.1 \mathrm{mg} \mathrm{m}^{-3}$ precision) equipped with a multiplexer to collect air samples at two heights (between and $0.25 \mathrm{~m}$ above slats, Figure 3 ) and at

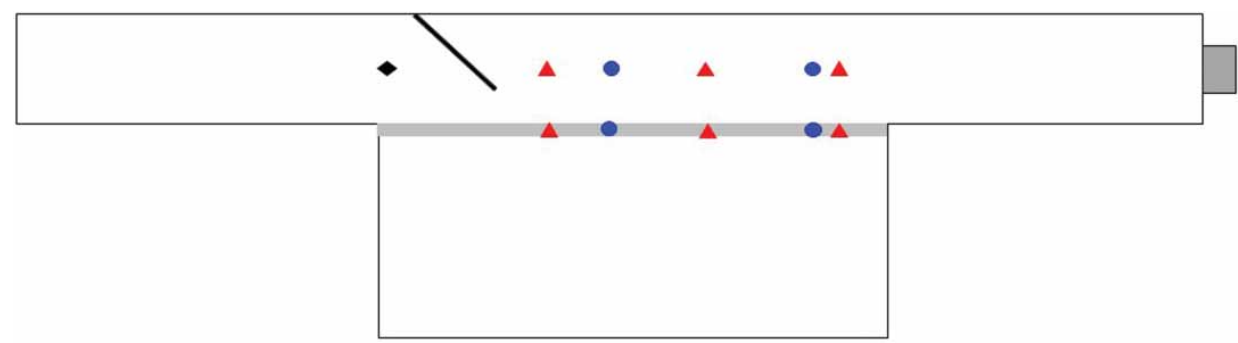

Figure 3. Longitudinal cross-section representation of the experimental wind tunnel (not to scale) at the middle distance from the lengthwise sides, indicating the positions of the anemometers ( $\bullet$ and $\bullet$ are for velocity measurements made at the inlet and inside the test section of the wind tunnel, respectively) and $\mathrm{NH}_{3}$ concentration sensors ( $\Delta$ ). 
three distances across the length of the measuring section of the wind tunnel ( $1 \mathrm{~m}$ apart from one another), leeward from the deflector panel. This sampling scheme yielded six measurements per cycle, plus one for background concentration measurements at the wind tunnel inlet. Samples of air from each point were consecutively taken at $5 \mathrm{~min}$ intervals, with the first $3 \mathrm{~min}$ for stabilization and the last 2 min for measurement, yielding a measurement cycle of 35 min for one complete loop. The air coming from each sampling port was channelled into the photoacoustic analyzer with fluoroethylene tubing ( $6.3 \mathrm{~mm}$ inside diameter). The successive sampling was accomplished through controlled operation of seven solenoid valves (CBISS Intelligent Sampling System MK2, Ballerup, Denmark).

All instruments used in this study were factory calibrated within 6 months prior to the beginning of the trials.

In order to certify that the wind tunnel system and the monitoring equipment were functioning properly and consistently over the course of the experiments, standard conditions for inlet $V R$ of $0.262 \mathrm{~m}^{3} \mathrm{~s}^{-1}$ (equivalent to an inlet air velocity of $\left.0.46 \mathrm{~m} \mathrm{~s}^{-1}\right), H H$ of $0.5 \mathrm{~m}$ and deflector panel angle $(D A)$ of $0^{\circ}$ were applied for a period of at least 48 hours prior to the start of the experiments. This procedure was repeated on a daily basis (between $6.00 \mathrm{pm}$ and $9.00 \mathrm{am}$ ), and the total execution time of the experiments in this study was 2 weeks.

\section{Experiments on varying inlet air $V R, H H$ and $D A$}

Two experiments were performed, one in which different levels of $V R$ and $D A$ were combined and tested, and another one where different levels of $H H$ and $D A$ were evaluated. In the first experiment, four different $V R(0.150$, $0.225,0.300$ and $0.375 \mathrm{~m}^{3} \mathrm{~s}^{-1}$ ) were applied to the exhaust fan of the wind tunnel, which resulted in $u_{\text {inlet }}$ values of $0.26,0.39,0.52$ and $0.65 \mathrm{~m} \mathrm{~s}^{-1}$, respectively. At each studied $V R$, five different airflow $D A$ were imposed through manipulation of the deflector panel inside the wind tunnel: $0^{\circ}$ (completely open), $20^{\circ}, 45^{\circ}, 70^{\circ}$ and $90^{\circ}$ (completely closed). During this experimental series, an intermediate $H H$ of $0.50 \mathrm{~m}$ was maintained.

In the second experiment, different levels of $H H$ were achieved by altering the height between the bottom of the slatted floor and the container that held the $\mathrm{NH}_{3}$-emitting solution. The tested $H H$ values were $0.10,0.37,0.63$ and $0.90 \mathrm{~m}$, which reflected different full-scale manure levels, which can occur in practice due to manure production. At each $H H$, five different $D A$ were imposed through the manipulation of the deflector panel inside the wind tunnel: $0^{\circ}, 20^{\circ}, 45^{\circ}, 70^{\circ}$ and $90^{\circ}$. A constant inlet $V R$ of $0.263 \mathrm{~m}^{3}$ $\mathrm{s}^{-1}$ was used, resulting in a $u_{\text {inlet }}$ of $0.46 \mathrm{~m} \mathrm{~s}^{-1}$.

In each experiment, the combination of 4 levels of $V R$ or $H H$ with 5 levels of $D A$ yielded a total of 20 trials, each lasting $70 \mathrm{~min}$, and performed at random. All 40 trials were performed within a 2 weeks period.

\section{Calculation algorithm for PTC}

In livestock manure, the ion ammonium $\left(\mathrm{NH}_{4}^{+}\right)$, which is the precursor of liquid $\mathrm{NH}_{3}\left(\mathrm{NH}_{3, \mathrm{~L}}\right)$, is the direct byproduct of mineralization of proteins and/or enzymatic degradation of urea. In our experiments, the ion $\mathrm{NH}_{4}^{+}$ was supplied by the $\mathrm{NH}_{4} \mathrm{Cl}$ solution. The conversion of $\mathrm{NH}_{4}^{+}$into $\mathrm{NH}_{3, \mathrm{~L}}$ is described as a reversible chemical reaction and is a function of the dissociation constant $\left(K_{\mathrm{D}}\right.$, Equation (2)). Higher $\mathrm{pH}$ values shift the equilibrium of Equation (2) to the right, and more $\mathrm{NH}_{3, \mathrm{~L}}$ will be available for volatilization. The volatilization of $\mathrm{NH}_{3, \mathrm{~L}}$ into gaseous $\mathrm{NH}_{3}\left(\mathrm{NH}_{3, \mathrm{G}}\right)$, is a function of the Henry $\left(K_{\mathrm{H}}\right)$ constant (Equation (3)).

$$
\begin{aligned}
{\left[\mathrm{NH}_{4}^{+}\right] } & \leftrightarrow\left[\mathrm{NH}_{3, L}\right]+\left[\mathrm{H}^{+}\right], \\
{\left[\mathrm{NH}_{3, L}\right] } & \leftrightarrow\left[\mathrm{NH}_{3, G}\right],
\end{aligned}
$$

where $\left[\mathrm{NH}_{4}^{+}\right]$is the concentration of the ion $\mathrm{NH}_{4}^{+}$at the emitting solution surface $\left(\mathrm{mg} \mathrm{m}^{-3}\right) ;\left[\mathrm{NH}_{3, L}\right]$ and $\left[\mathrm{NH}_{3, G}\right]$ are the liquid and gaseous concentrations of $\mathrm{NH}_{3}$, respectively, at the emitting solution surface $\left(\mathrm{mg} \mathrm{m}^{-3}\right) ;\left[\mathrm{H}^{+}\right]$is the proton concentration at the surface of the aqueous solution and $\left(\left[\mathrm{H}^{+}\right]=10^{-\mathrm{pH}}=10^{-8} \mathrm{mg} \mathrm{m}^{-3}\right.$ at a $\mathrm{pH}$ of 8.00).

The constants $K_{\mathrm{D}}$ and $K_{\mathrm{H}}$ are the dissociation and Henry constants (dimensionless), respectively. They can be calculated using Equations (4) [34] and 5 [35], respectively:

$$
\begin{aligned}
& K_{D}=10^{-(0.0897+(2729 / T))}, \\
& K_{H}=10^{-1.69+(1477.7 / T),}
\end{aligned}
$$

where $T$ is the emitting solution surface temperature $(\mathrm{K})$.

Since it is not possible to measure $\left[\mathrm{NH}_{3, L}\right]$ directly, it was estimated as a function of [TAN], $\left[\mathrm{H}^{+}\right]$and $K_{\mathrm{D}}$, as presented in Equation (6):

$$
\left[\mathrm{NH}_{3, L}\right]=[\mathrm{TAN}] /\left(1+\left(\left[\mathrm{H}^{+}\right] / K_{D}\right)\right)
$$

where [TAN] is the total ammonia nitrogen concentration at the emitting solution surface $\left(10^{8} \mathrm{mg} \mathrm{m}^{-3}\right)$.

The relationship between $\left[\mathrm{NH}_{3, L}\right]$ and $\left[\mathrm{NH}_{3, G}\right]$ is given by Equation (7):

$$
\left[\mathrm{NH}_{3, G}\right]=\left[\mathrm{NH}_{3, L}\right] / K_{H} .
$$

In this study, $P T C$ was calculated using Equation (8):

$$
P T C=\left(V R_{\mathrm{STD}} \times\left[\mathrm{NH}_{3}\right]\right) /\left(\left(A_{S}\right) \times\left[\mathrm{NH}_{3, G}\right]\right),
$$

where PTC is the pit mass transfer coefficient of $\mathrm{NH}_{3}$ (m $\left.\mathrm{s}^{-1}\right) ; V R_{\mathrm{STD}}$ is the ventilation rate corrected for standard pressure (1 atmosphere) and temperature $\left(25^{\circ} \mathrm{C}\right)\left(\mathrm{m}^{3} \mathrm{~s}^{-1}\right)$; $\left[\mathrm{NH}_{3}\right]$ is the mean concentration of $\mathrm{NH}_{3}$ measured between and above the slats $\left(\mathrm{mg} \mathrm{m}^{-3}\right)$; and $A_{\mathrm{s}}$ is the emitting solution surface area $\left(2.40 \mathrm{~m}^{2}\right)$.

Values of PTC from this study were compared with $k_{\mathrm{NH}_{3}}$ values calculated from the models presented in other studies (Table 1). 
Table 1. Considered studies on $\mathrm{NH}_{3}$ mass transfer coefficient $\left(k_{\mathrm{NH}_{3}}, \mathrm{~m} \mathrm{~s}^{-1}\right)$ modelling.

\begin{tabular}{|c|c|c|}
\hline Source & Study conditions & Model \\
\hline Ikeguchi and Kamo [36] & Dairy cattle manure, wind tunnel study & $\begin{array}{l}k_{\mathrm{NH}_{3}}=0.00629 \times u^{1.712} \\
\text { Where } u \text { is the air velocity }\left(\mathrm{m} \mathrm{s}^{-1}\right)\end{array}$ \\
\hline Ye et al. [27] & Aqueous solution, pig house model study & $\begin{array}{l}k_{\mathrm{NH}_{3}}=0.00171 \times u^{-0.0038} \times(100 \times T I)^{0.28} \\
\text { Where } u \text { is the air velocity }\left(\mathrm{m} \mathrm{s}^{-1}\right) \text { and } T I \text { is turbulence } \\
\quad \text { intensity (dimensionless) }\end{array}$ \\
\hline Rong et al. [37] & Aqueous solution, wind tunnel study & $\begin{array}{l}k_{\mathrm{NH}_{3}}=0.00179 \times u^{0.38} \times(100 \times T I)^{0.24} \\
\text { Where } u \text { is the air velocity }\left(\mathrm{m} \mathrm{s}^{-1}\right) \text { and } T I \text { is turbulence } \\
\text { intensity (dimensionless) }\end{array}$ \\
\hline Saha et al. [38] & Aqueous solution, wind tunnel study & $\begin{array}{l}k_{\mathrm{NH}_{3}}=0.00126 \times u^{0.34} \times(100 \times T I)^{0.21} \\
\text { Where } u \text { is the air velocity }\left(\mathrm{m} \mathrm{s}^{-1}\right) \text { and } T I \text { is turbulence } \\
\quad \text { intensity (dimensionless) }\end{array}$ \\
\hline Vaddella et al. [39] & Dairy cattle manure, wind tunnel study & $\begin{array}{l}k_{\mathrm{NH}_{3}}=\left(4.85 \times 10^{-11} \times T_{L} 9.7 \times u^{0.34}\right) /\left(T^{8.02} \times T S^{0.26}\right) \\
\text { Where } T_{\mathrm{L}} \text { is the liquid temperature }\left({ }^{\circ} \mathrm{C}\right), u \text { is the air velocity } \\
\left(\mathrm{m} \mathrm{s}^{-1}\right), T \text { is the air temperature }\left({ }^{\circ} \mathrm{C}\right) \text { and } T S \text { is the total } \\
\text { solids content of manure (assumed to be } 1.5 \%)\end{array}$ \\
\hline
\end{tabular}

\section{Data processing and statistical analyses}

With the data collected for system check-up tests, the values of the following variables were averaged over periods of at least $15 \mathrm{~h}: \mathrm{NH}_{4} \mathrm{Cl}$ solution $p H$ and temperature $\left(T_{\text {sol }}\right.$, $\left.{ }^{\circ} \mathrm{C}\right)$, along with air velocity at the inlet $\left(u_{\text {inlet }}, \mathrm{m} \mathrm{s}^{-1}\right)$ and inlet air temperature $\left(T_{\text {inletair }},{ }^{\circ} \mathrm{C}\right)$ measured inside the wind tunnel, $0.25 \mathrm{~m}$ above the slats. During this period, the conditions remained approximately constant. One sample two-sided $t$-test was performed on $p H$ and $u_{\text {inlet }}$, in order to test the hypothesis that mean values were not significantly different from the expected values of 8.00 and $0.46 \mathrm{~m} \mathrm{~s}^{-1}$, respectively. One sample two-sided $t$-test was also applied on the variables $T_{\text {sol }}$ and $T_{\text {inletair }}$ in order to test the hypothesis that individual values measured every $15 \mathrm{~h}$ period were not significantly different from the mean value over all periods. The $t$-test analyses were performed with the procedure ttest in SAS ${ }^{\circledR}$ (Version 9.4, Cary, North Carolina, USA).

During experiments, data collected on the dependent variables $\left[\mathrm{NH}_{3}\right]$ and $u$ at every trial were averaged over the measurement period $(70 \mathrm{~min})$. Then calculations of $T I$ were performed with $u$ data by using Equation (1).

In order to determine the influence of the factors $V R$, $D A$ and $H H$ on the dependent variables $\left[\mathrm{NH}_{3}\right], u$ and $T I$, linear regression analysis was performed. It was expected that, for a specific variable, the sampling positions between slats versus $0.25 \mathrm{~m}$ above the slats would significantly impact $\left[\mathrm{NH}_{3}\right], u$ and $T I$. Distinct regression models were obtained for the explained variables at the slats level and at $0.25 \mathrm{~m}$ above slats. For each dependent variable, two different models were developed, one combining $H H$ and $D A$ and another one with $V R$ and $D A$. The analysis was done with the procedure generalized linear mixed models (procglm) in SAS ${ }^{\circledR}$ to test whether the combined effects of the continuous $V R$ and $D A$ or $H H$ and $D A$, along with their interactions, could be explained by the respective fixed effects model described in Equations (9) or (10):

$$
Y_{i j}=\alpha+\beta_{1} \cdot V R_{i}+\beta_{2} \cdot D A_{j}+\beta_{3} \cdot\left(V R_{i} \times D A_{j}\right)+\varepsilon_{i j},
$$

or

$Y_{i j}=\alpha+\beta_{1} \cdot H H_{i}+\beta_{2} \cdot D A_{j}+\beta_{3} \cdot\left(H H_{i} \times D A_{j}\right)+\varepsilon_{i j}$,

where $Y_{i j}$ is the measured $\left[\mathrm{NH}_{3}\right], u$ or $T I ; V R_{\mathrm{i}}$ is the effect of the ventilation rate $\left(0.150,0.225,0.300\right.$ and $0.375 \mathrm{~m}^{3}$ $\mathrm{s}^{-1}$ ) on $\left[\mathrm{NH}_{3}\right], u$ or $T I$, here considered a continuous variable; $H H_{\mathrm{i}}$ is the effect of the pit headspace height $(0.10$, $0.37,0.63$ and $0.90 \mathrm{~m}$ ) on $\left[\mathrm{NH}_{3}\right], u$ or $T I$, here considered a continuous variable; $D A_{\mathrm{i}}$ is the effect of the deflection panel angle $\left(0^{\circ}, 20^{\circ}, 45^{\circ}, 70^{\circ}\right.$ and $\left.90^{\circ}\right)$ on $\left[\mathrm{NH}_{3}\right], u$ or $T I$, here considered a continuous variable; $\beta_{1}, \beta_{2}$ and $\beta_{3}$ are regression coefficients obtained from the analysis; $\alpha$ is the intercept, obtained from the analysis and $\epsilon_{i j}$ is the independent normally distributed homogeneous random error.

In order to allow the comparison with $k_{\mathrm{NH}_{3}}$ from the studies mentioned in Table 1, non-linear regression was performed with the PTC data calculated in this study against $u$ according to the model in Equation (11). The shape of Equation (11) was chosen because according to theory, the mass transfer coefficient is expected to vary with $u$ according to a power function.[20] This analysis was performed with the procedure procnlin in SAS ${ }^{\circledR}$.

$$
P T C=a \times u^{b},
$$

where $P T C$ is the transfer coefficient of $\mathrm{NH}_{3}$ from the pit $\left(\mathrm{m} \mathrm{s}^{-1}\right) ; u$ is the local air velocity $\left(\mathrm{m} \mathrm{s}^{-1}\right)$ measured between slats and $a$ and $b$ are regression coefficients obtained from the analysis.

All statistical analyses in this paper were performed for a significance level of 0.05 , and the fit of the models 
was evaluated by an examination of the normal probability plots of the residuals and by inspection of the residuals plotted against the predicted values.

\section{Results and discussion}

\section{Performance of the system}

The results of the statistical analysis performed on the variables monitored during the check-up tests prior to the start of the experiments and throughout the experimental period are summarized in Table 2. The overall measured $p H$ of the aqueous solution was $8.02 \pm 0.03$, which was not significantly different from the set-point value of 8.00 $(p=.086)$. This outcome suggests that the automatic $p H$ buffering system was working properly and consistently during the experiments. The average value for the variable $u_{\text {inlet }}$ monitored under standard conditions $\left(V R=0.262 \mathrm{~m}^{3}\right.$ $\mathrm{s}^{-1}, H H=0.5 \mathrm{~m}$ and $D A=0^{\circ}$ ) was $0.47 \pm 0.01 \mathrm{~m} \mathrm{~s}^{-1}$, and was not significantly different from the expected value of $0.46 \mathrm{~m} \mathrm{~s}^{-1}(p=.089)$, indicating that the velocity given by the hot-wire anemometer agreed with the expected velocity of the exhaust fan. This outcome also indicates that, in averaged terms, the drag effect due to the presence of the sensors and sampling ports did not allow for a significant pressure drop inside the test section of the wind tunnel that could affect average air velocities. Hence, this drag effect of the presence of sensors and sampling ports was considered negligible. In fact, a Computational Fluid Dynamic (CFD) study performed in order to allow detailed visualization of the flow patterns inside the test section of the wind tunnel (data not presented) indicated that the modelled air velocities at the same locations where the sensors and sampling ports were placed agreed well with the air velocities measured experimentally.[40]

Concerning the variable $T_{\text {inletair }}$ the $t$-test results indicated that some of the measurements did statistically differ from the overall mean $(p=.001)$; however, temperature values spanned between $16.0^{\circ} \mathrm{C}$ and $18.3^{\circ} \mathrm{C}$, which is considered a relatively small range for the purposes of this research study, meaning that this significant effect is not relevant. A similar outcome was observed for $T_{\text {sol }}$, with a mean value of $16.6 \pm 0.4^{\circ} \mathrm{C}$, but with the measured maximum and minimum values differing by only $0.9^{\circ} \mathrm{C}$.

In general, it was observed that the variability of the monitored variables during the check-up tests was relatively small, indicating that the ventilation system of the wind tunnel and the conditions of the aqueous solution presented good stability and repeatability during the trials.

\section{Effects of varying inlet $V R$ and $D A$}

The equations resulting from the regression analysis on the effects of $V R$ and $D A$ on $u, T I$ and $\left[\mathrm{NH}_{3}\right]$ are presented in Table 3, while the mean values are graphically shown in Figure 4 . The results indicate that $u$ significantly increased with increasing $D A(p=.001)$ at the slats level, and significantly decreased with $D A(p=.001)$ at $0.25 \mathrm{~m}$ from slats. This outcome was expected, because as the deflection panel was lowered (increasing $D A$ ), the flow at 0.25 $\mathrm{m}$ was obstructed, resulting in lower average air velocities, while forcing the air to move through the decreasing size opening between the deflection panel and the slats, yielding higher average air velocities near the slats. Concerning the variable $V R$, the statistical analysis indicated that $u$ was positively impacted by $V R$ at both heights

Table 2. Results from the $t$-test analysis performed on the variables measured during the wind tunnel system check-up.

\begin{tabular}{|c|c|c|c|c|c|c|}
\hline Variable & Expected value & Measured value (mean $\pm \mathrm{SE}$ ) & Min. value & Max. value & $n^{\mathrm{a}}$ & $p$-value ${ }^{\mathrm{b}}$ \\
\hline$p H$ & 8.00 & $8.02 \pm 0.03$ & 8.00 & 8.09 & 8 & 0.086 \\
\hline$u_{\text {inlet }}\left(\mathrm{m} \mathrm{s}^{-1}\right)$ & 0.46 & $0.47 \pm 0.01$ & 0.44 & 0.48 & 8 & 0.089 \\
\hline$T_{\text {inletair }}\left({ }^{\circ} \mathrm{C}\right)$ & - & $17.0 \pm 0.3$ & 16.0 & 18.3 & 8 & 0.001 \\
\hline$T_{\text {sol }}\left({ }^{\circ} \mathrm{C}\right)$ & - & $16.6 \pm 0.4$ & 16.1 & 17.0 & 8 & 0.001 \\
\hline
\end{tabular}

a Number of observations.

${ }^{\mathrm{b}} p$-Values smaller than .050 were considered significant in this study.

Table 3. Summary of the results from the linear regression analysis for the effects of $V R\left(\mathrm{~m}^{3} \mathrm{~s}^{-1}\right)$ and $D A\left(^{\circ}\right)$ at each sampling height (between slats and at $0.25 \mathrm{~m}$ above slats) inside the wind tunnel on air velocity $(u, \mathrm{~m}$ $\left.\mathrm{s}^{-1}\right), T I$ (dimensionless) and $\mathrm{NH}_{3}$ concentrations $\left(\left[\mathrm{NH}_{3}\right], \mathrm{mg} \mathrm{m}^{-3}\right)$.

\begin{tabular}{lll}
\hline Variable & \multicolumn{1}{c}{ Height } & \multicolumn{1}{c}{ Regression model } \\
\hline$u$ & Between slats & $u=(0.23 \pm 0.12) \cdot V R+(0.0034 \pm 0.0006) \cdot D A$ \\
$u$ & 0.25 m above slats & $u=(2.2 \pm 0.2) \cdot V R+(-0.003 \pm 0.001) \cdot D A$ \\
$T I$ & Between slats & $T I=(1.4 \pm 0.3) \cdot V R+(0.006 \pm 0.003) \cdot D A-(0.03 \pm 0.01) \cdot V R \times D A$ \\
$T I$ & 0.25 m above slats & $T I=(0.97 \pm 0.02) \cdot V R+(0.0003 \pm 0.0001) \cdot D A$ \\
{$\left[\mathrm{NH}_{3}\right]$} & Between slats & {$\left[\mathrm{NH}_{3}\right]=(52 \pm 6)+(-0.37 \pm 0.11) \cdot D A$} \\
{$\left[\mathrm{NH}_{3}\right]$} & $0.25 \mathrm{~m}$ above slats & {$\left[\mathrm{NH}_{3}\right]=(7 \pm 3)+(0.14 \pm 0.05) \cdot D A$} \\
\hline
\end{tabular}



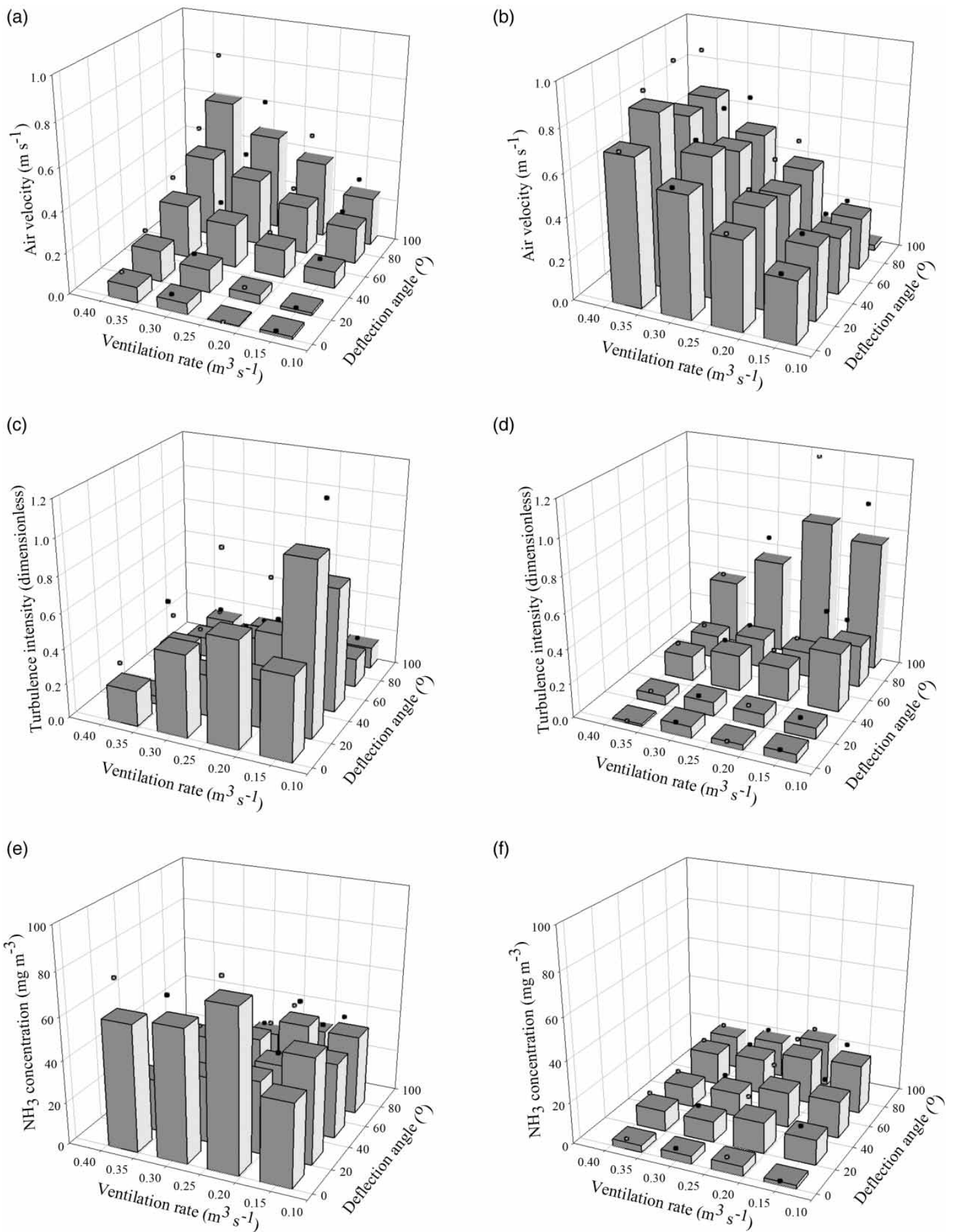

Figure 4. Air velocity $\left(u, \mathrm{~m} \mathrm{~s}^{-1}\right.$; a and b), TI (dimensionless; $\mathrm{c}$ and d) and $\mathrm{NH}_{3}$ concentration $\left(\left[\mathrm{NH}_{3}\right], \mathrm{mg} \mathrm{m}^{3}\right.$; e and $\left.\mathrm{f}\right)$ plotted against $V R\left(\mathrm{~m}^{3} \mathrm{~s}^{-1}\right)$ and $D A\left(^{\circ}\right)$. Charts to the left refer to variables monitored between slats and the charts to the right are for variables measured at $0.25 \mathrm{~m}$ above the slats. Dots placed above each bar represent the upper limit of the $95 \%$ confidence interval.

$(p=.010$ and $p=.001$ at the slats level and at $0.25 \mathrm{~m}$ above slats, respectively). As for the dependent variable $T I$, in general, the barcharts in Figure 4(c) and 4(d) seem to be inversely related to those presented in Figure 4(a) and 4 (b), respectively, except for lower range of $V R=0.150$ $\mathrm{m}^{3} \mathrm{~s}^{-1}$, where $T I$ was likely overestimated by the very small measured $u$ values. This means that higher $T I$ values were observed where $u$ was low, and vice-versa. A similar outcome was observed by Saha et al. [38]. In addition, Townsend [41] demonstrated that the occurrence of 
higher $T I$ at lower $u$ is an indication of a highly intermittent flow regime, which might be associated with a higher volatilization rate of $\mathrm{NH}_{3}$.

In Figure 4(c) it can be seen that high $T I$ values were observed at low $D A\left(0^{\circ}\right)$, while in Figure 4(d) low $T I$ occurred at $D A=90^{\circ}$. These relatively high values for TI might not have any physical meaning concerning the description of flow characteristics, as they originated from the use of respective low $u$ values (Figure 4(a) and 4(b), respectively) plugged into Equation (1).

The results in Table 3 reveal that the variable $\left[\mathrm{NH}_{3}\right]$ was significantly impacted by $D A(p<.001)$ at the slats level. This outcome implies that when $D A$ was increased, $u$ reached higher values. In Figure 4(e) one can see that the concentrations measured between the slats were higher at lower $D A$ values, while an inverse trend was observed at $0.25 \mathrm{~m}$ above slats (Figure 4(e)). This outcome suggests the presence of a negative concentration gradient between the slat level and the height of $0.25 \mathrm{~m}$ (Figure 4(f)). A similar outcome was obtained by Mendes et al. [42] when monitoring concentrations of $\mathrm{NH}_{3}$, carbon dioxide $\left(\mathrm{CO}_{2}\right)$ and sulfur hexafluoride $\left(\mathrm{SF}_{6}\right.$, artificially injected) at different heights above the slats $(1-4 \mathrm{~m})$ in a naturally ventilated dairy cow barn. Gaseous concentrations will tend to decrease at larger distances from the emitting source due to dilution,[20] the aqueous solution surface in the case of this study, when cross air flow is present.

In the conditions of this experiment, the statistical analysis revealed that at the slats level, $V R$ did not affect $\left[\mathrm{NH}_{3}\right]$ $(p=.134)$. However, it was significantly affected by $D A$ $(p<.001)$, both between and $0.25 \mathrm{~m}$ above slats.

This outcome indicates that, in the conditions of this study, $V R$ itself was not relevant to the $\left[\mathrm{NH}_{3}\right]$ profile, while the different air flow patterns created with different $D A$ did affect $\left[\mathrm{NH}_{3}\right]$ distribution between above the slats. One practical implication of this is that any $V R$ values will only enhance the volatilization and transport of $\mathrm{NH}_{3}$ if air currents entering the livestock barn are diverted towards the emission surface.[14,15] On the other hand, if the main air stream remains well above the emission surface, the mass transfer will take much longer to occur.

Ye et al. [27] and Ye et al. [43], with laboratory reduced scale studies of a pig barn model with an aqueous solution of $\mathrm{NH}_{3}$, indicated that inlet $V R$ did reduce $\left[\mathrm{NH}_{3}\right]$. In these studies, the inlet air entered the model through ventilation flaps placed at side walls and just underneath the ceiling. This means that at least part of the fresh air entering the model passed through the slats, thus getting into direct contact with the aqueous solution. With this configuration, an interaction between $V R$ and the flow pattern itself might have significantly impacted $\left[\mathrm{NH}_{3}\right]$.

\section{Effects of $\mathrm{HH}$ and $\mathrm{DA}$}

The regression equations resulting from the analysis on the effects of $H H$ and $D A$ on $u, T I$ and $\left[\mathrm{NH}_{3}\right]$ are given in Table 4 and the averaged values are plotted in Figure 5 . The analysis indicated that within the tested range of $0.10-0.63$ $\mathrm{m}$, the factor $H H$ did not have a significant effect on any of the explained variables $(.172<p<.890)$. This result can be seen in Figure 5(a)-5(d), meaning that no adverse effect of $H H$ on the average air velocity between or above the slats was observed. As a consequence, $\left[\mathrm{NH}_{3}\right]$ monitored between and above the slats (Figure 5(e) and 5(f), respectively) also remained approximately constant across different $H H$ values. This result suggests that, at a given constant $D A$, the increasing proximity of the aqueous solution surface to the slats (achieved by decreasing $H H$ ), and thus to the main air flow stream, did not lead to higher volatilization of $\mathrm{NH}_{3}$.

Because no significant interactive effect of $H H$ was present in this study $(p=.756)$, the results from this experiment can be used to specifically address the effect of guiding the air through the slats on $\left[\mathrm{NH}_{3}\right]$. The significant impact of $D A$ on $u, T I$ and $\left[\mathrm{NH}_{3}\right]$ can be visualized in Figure 5 and Table 4 . The factor $D A$ significantly affected all three monitored explained variables $(.001<p<.003)$. These outcomes support the results of the experiment with $V R \times D A$ previously discussed in this study that changing air flow patterns significantly impacted $\left[\mathrm{NH}_{3}\right]$ distribution near the slatted floor. Morsing et al. [44] found that effects on air flow patterns inside pig barn models equipped with different manure channel layouts and floor types on average barn $\left[\mathrm{NH}_{3}\right]$ were significant. Those authors hypothesized that the effects on gas emissions are a consequence of changing air flow patterns and different types of flow in the boundary layer between manure and air.

Table 4. Summary of the results from the linear regression analysis for the effects of $H H(\mathrm{~m})$ and $D A \quad\left({ }^{\circ}\right)$ at each sampling height (between slats and at $0.25 \mathrm{~m}$ above slats) inside the wind tunnel on air velocity $\left(u, \mathrm{~m} \mathrm{~s}^{-1}\right), T I$ (dimensionless) and $\mathrm{NH}_{3}$ concentrations $\left(\left[\mathrm{NH}_{3}\right], \mathrm{mg} \mathrm{m}^{-3}\right)$.

\begin{tabular}{lll}
\hline Variable & \multicolumn{1}{c}{ Height } & \multicolumn{1}{c}{ Regression model } \\
\hline$U$ & At slats & $u=(0.0044 \pm 0.0005) \cdot D A$ \\
$U$ & $0.25 \mathrm{~m}$ above slats & $u=(-0.008 \pm 0.001) \cdot D A$ \\
$T I$ & At slats & $T I=(0.002 \pm 0.001) \cdot D A$ \\
$T I$ & $0.25 \mathrm{~m}$ above slats & $T I=(0.0059 \pm 0.0009) \cdot D A$ \\
{$\left[\mathrm{NH}_{3}\right]$} & At slats & {$\left[\mathrm{NH}_{3}\right]=(47 \pm 5)+(-0.37 \pm 0.09) \cdot D A$} \\
{$\left[\mathrm{NH}_{3}\right]$} & $0.25 \mathrm{~m}$ above slats & {$\left[\mathrm{NH}_{3}\right]=(6 \pm 2)+(0.14 \pm 0.04) \cdot D A$} \\
\hline
\end{tabular}



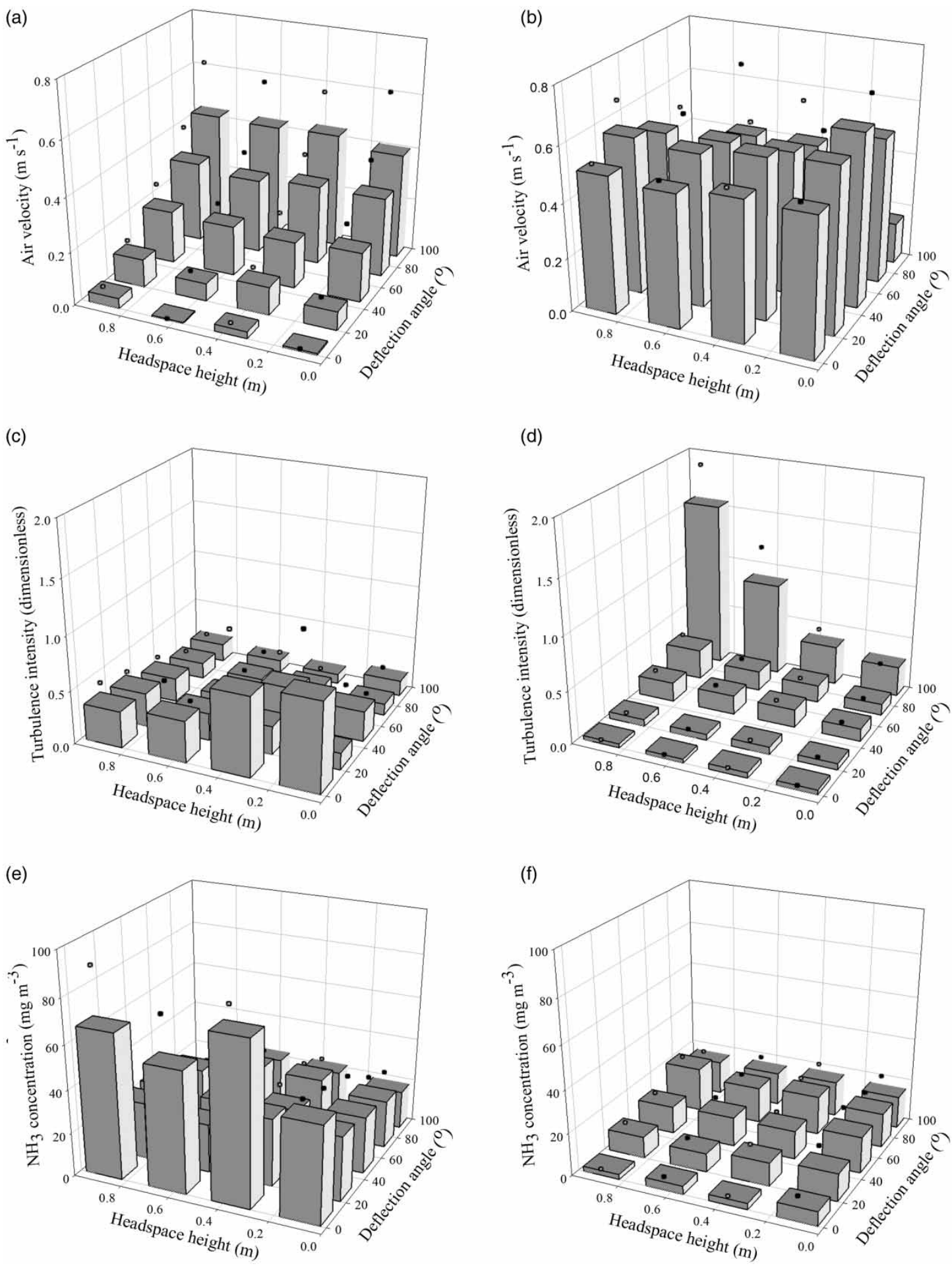

Figure 5. Air velocity $\left(u, \mathrm{~m} \mathrm{~s}^{-1}\right.$; a and b), TI (dimensionless; $\mathrm{c}$ and d) and $\mathrm{NH}_{3}$ concentration $\left(\left[\mathrm{NH}_{3}\right]\right.$, $\mathrm{mg} \mathrm{m}^{3}$; e and $\mathrm{f}$ ) plotted against $H H(\mathrm{~m})$ and $D A\left(^{\circ}\right)$. Charts to the left refer to variables monitored between slats and the charts to the right are for variables measured at $0.25 \mathrm{~m}$ above the slats. Dots placed above each bar represent the upper limit of the $95 \%$ confidence interval.

\section{Calculations of PTC}

The results for the non-linear regression performed for PTC data are presented in Figure 6(a). Figure 6(b) shows the obtained regressed curve amongst the selected models for $k_{\mathrm{NH}_{3}}$ from other studies (Table 1).
It can be seen from the plot in Figure 6(b) that, for $u$ ranging between 0.1 and $0.7 \mathrm{~m} \mathrm{~s}^{-1}$, the model for $P T C$ from this study is quite comparable to those obtained for $k_{\mathrm{NH}_{3}}$ from other studies. The average values for $k_{\mathrm{NH}_{3}}$ calculated over the considered velocity range are presented 

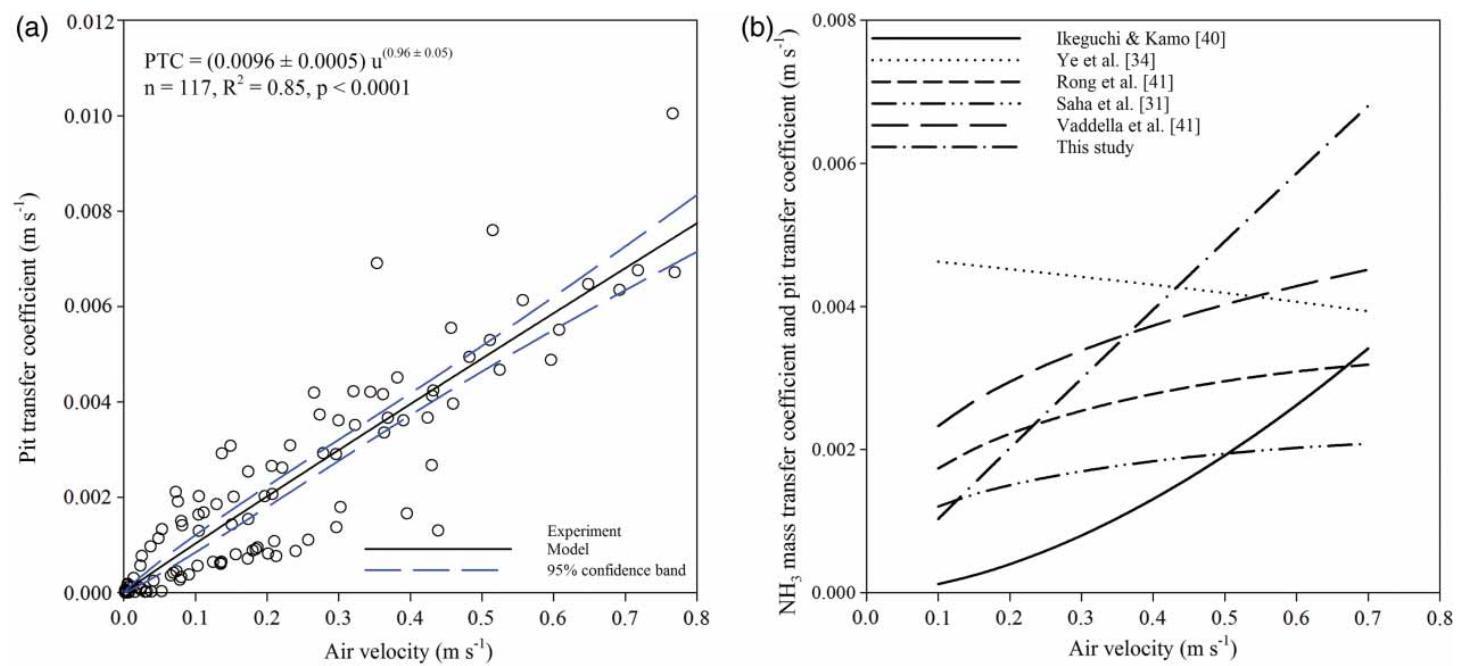

(c)

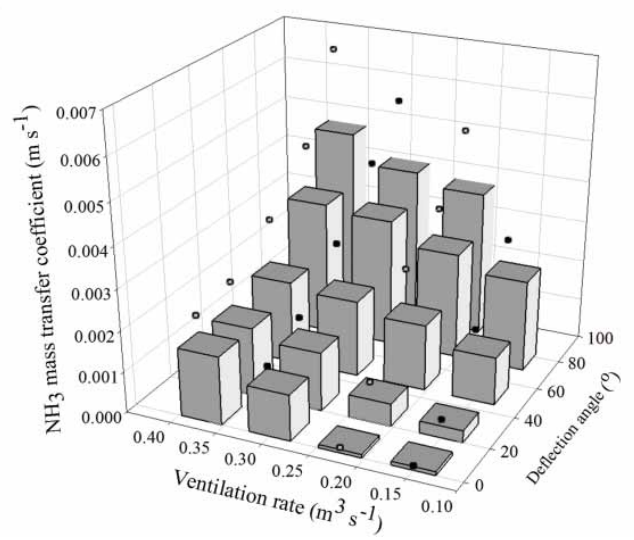

(d)

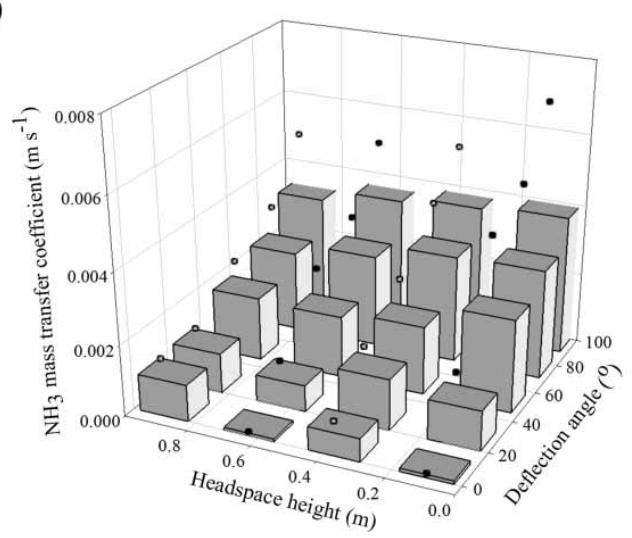

Figure 6. Regression curve for $P T C$ of $\mathrm{NH}_{3}\left(\mathrm{~m} \mathrm{~s}^{-1}\right)$ (a); $P T C$ curve from this study plotted together with $\mathrm{NH}_{3}$ mass transfer coefficients $\left(k_{\mathrm{NH}_{3}}, \mathrm{~m} \mathrm{~s}^{-1}\right)$ from other studies (b). Bar charts of the effects of $V R(\mathrm{~m})$ versus $D A\left(^{\circ}\right)$ on $P T C$, and (c) and of the effects of $H H(\mathrm{~m})$ versus $D A(\mathrm{~d})$ on $P T C, \mathrm{~m} \mathrm{~s}^{-1}$, monitored in the test section of the wind tunnel. Dots placed above each bar represent the upper limit of the $95 \%$ confidence interval.

Table 5. Averaged mass transfer coefficients $\left(k_{\mathrm{NH}_{3}}, \mathrm{~m}\right.$ $\left.\mathrm{s}^{-1}\right)$ and $P T C\left(\mathrm{~m} \mathrm{~s}^{-1}\right)$ of $\mathrm{NH}_{3}$ calculated over the air velocity range of $0.1-0.7 \mathrm{~m} \mathrm{~s}^{-1}$.

\begin{tabular}{lc}
\hline Source & Average $k_{\mathrm{NH}_{3}}$ or PTC $\left(\mathrm{m} \mathrm{s}^{-1}\right)$ \\
\hline Ikeguchi and Kamo [36] & 0.0015 \\
Ye et al. [27] & 0.0043 \\
Rong et al. [37] & 0.0027 \\
Saha et al. [38] & 0.0018 \\
Vaddella et al. [39] & 0.0036 \\
This study & 0.0039 \\
\hline
\end{tabular}

in Table 5. The average PTC was $0.0039 \mathrm{~m} \mathrm{~s}^{-1}$, which was included in the range defined by the average $k_{\mathrm{NH}_{3}}$ of $0.0015-0.0043 \mathrm{~m} \mathrm{~s}^{-1}$ from different studies. This outcome indicates that compared to the determination of $k_{\mathrm{NH}_{3}}$, the simplification added to the determination of PTC by measuring gaseous concentrations between slats instead of right on top of the manure surface can still yield values that are comparable to those measured in the laboratory. The main consequence of this outcome is that the methodology for the determination of PTC determined in this study could be applied to real cattle barns in order to help answering questions concerning influencing factors of the emissions from the manure pit. Although it was not the main objective of the current study, measurements of PTC between slats in real dairy cattle barns are recommended in future studies.

The regression models for the variable $P T C$, similarly to the statistical models in Equations (9) and (10), are presented as Equations (12) and (13), respectively. The values of $P T C$ plotted against $V R \times D A$ and $H H \times D A$ are shown in Figure 6(c) and 6(d), respectively. For the experiment involving $V R \times D A$, a similar outcome as to what was observed for $\left[\mathrm{NH}_{3}\right]$ was also observed on PTC. In other words, VR had a significant impact on PTC $(p=.038)$. Ye et al. [27] found that the effect of $H H$ had a relatively small, but significant inverse correlation with $\mathrm{NH}_{3}$ emissions in a reduced scale model of a pig barn with aqueous solution. 
On the other hand, $\mathrm{Ni}$ et al. [16] when monitoring $\mathrm{NH}_{3}$ emissions from a full-scale pig barn, found no clear relationship between $\mathrm{NH}_{3}$ emission and $H H$. Similar results were found by Ye et al. [45], when monitoring $\mathrm{NH}_{3}$ emissions in a full-scale experimental pig room. The studies of Ni et al. [16] and Ye et al. [45] at full scale were more comparable to this study than the work described by Ye et al. [43] for reduced scale models. Whereas, a rather weak but significant effect of $H H$ was found with reduced scale, such effect is not found in this study. This outcome might have stemmed from the fact that, although this was a wind tunnel study, care was taken that some aspects were kept close to practical situations (the slatted floor is scaled 1:1; the inlet velocity is representative of velocities that actually happen near the floor of dairy cattle barns [15] and $H H$ values were also chosen to be realistic), which yielded PTC values that are closer to mass transfer coefficient values from studies conducted in full-scale livestock barns, than reduced scale wind tunnel ones.

On the other hand, the novelty aspect that this study brings, as compared to the results of $\mathrm{Ni}$ et al. [16] and Ye et al. [45], is that a full-scale section of slatted floor placed inside a wind tunnel allows for better control of the variables of interest. While in the studies of $\mathrm{Ni}$ et al. [16] and Ye et al. [45] the weak correlation found between $\mathrm{NH}_{3}$ emissions and $H H$ might have been due to high uncertainty levels, the increased accuracy of this study makes the non-existent effect of $H H$ on emissions more clear:

$$
\begin{aligned}
& P T C=(7 \pm 3) \times 10^{-10} \cdot V R+(8 \pm 2) \times 10^{-12} \cdot D A \\
& P T C=(1.0 \pm 0.1) \times 10^{-11} \cdot D A
\end{aligned}
$$

A positive significant effect of $D A$ on $P T C$ was observed in the experiment involving $H H$ vs. $D A$ $(p<.0001)$, and can be seen in Figure 6(d). When looking at the effect of $H H$ on $P T C$, the statistical analysis shows that a change in $H H$ did not lead to a significant change in $P T C$. This outcome is linked to the non-significant effect of $H H$ on $u, T I$ and $\left[\mathrm{NH}_{3}\right]$, as previously discussed in this study. While a positive interaction existed between $D A$ and PTC (Equations (12) and (13)), DA was negatively correlated with $\left[\mathrm{NH}_{3}\right]$ near the slats (Table 2). This outcome stems from the fact that the higher air velocities near the slats were associated with reduced $\left[\mathrm{NH}_{3}\right]$, which means that more $\mathrm{NH}_{3}$ was transported from the pit to above the slats and out of the wind tunnel (higher PTC). Consequently, lower $P T C$ values may be achieved when the main air stream is guided well above the slats.

Practical implications from this outcome might be drawn in order to reduce $\mathrm{NH}_{3}$ volatilization. For instance, relatively high $V R$ values could be practiced in a dairy cow barn in order to keep indoor air quality at its healthy levels, as long as the main airstream is placed above the animal occupied zone, such as the case of crossed flow ventilation.
The outcomes of this study indicate that the methodology for the determination of PTC in real dairy cattle barns with slatted floor is feasible and yielded results that are comparable to other laboratory studies. However, measurements of PTC in a real barn will make it cumbersome to separate the fraction of $\mathrm{NH}_{3}$ transferred from the manure pit and the floor itself. Hence, adaptations to this methodology for the determination of PTC in real livestock barns must be taken. These adaptations were out of the scope of this study, and might be a subject for future research.

\section{Conclusions}

A wind tunnel system was built in the laboratory, which featured a section of a slatted floor typically used in dairy cow barns. The manure pit was represented by an $\mathrm{NH}_{3}-$ emitting aqueous solution. Measurements of $u, T I$ and $\left[\mathrm{NH}_{3}\right]$ were monitored between slats and at $0.25 \mathrm{~m}$ above slats. PTC was calculated for the entire test section of the wind tunnel and compared with $k_{\mathrm{NH}_{3}}$ determined from other scientific studies. The effects of changing inlet $V R$, guiding the inlet air towards the slats and different $H H$ on $u, T I,\left[\mathrm{NH}_{3}\right]$ and PTC were tested. The following conclusions can be drawn:

(1) The variability of the inlet velocity and aqueous solution $\mathrm{pH}$ were relatively small $(0.47 \pm 0.01 \mathrm{~m}$ $\mathrm{s}^{-1}$ and $8.02 \pm 0.03$, respectively), indicating that the ventilation system of the wind tunnel and the conditions of the aqueous solution presented good stability and repeatability.

(2) The PTC values obtained in this study presented a good fit to the power function of the air speed near the slats $(u)(p<.001)$ and the average PTC $\left(0.0039 \mathrm{~m} \mathrm{~s}^{-1}\right)$ was comparable to $k_{\mathrm{NH}_{3}}$ values obtained from other studies, by remaining within the range of average values of $0.0015-0.0043 \mathrm{~m}$ $\mathrm{s}^{-1}$

(3) $V R$ alone did not affect $\left[\mathrm{NH}_{3}\right](p=.134)$. However, the change in the flow patterns near the slats (by changing $D A$ ) did impact the concentration profile and the transfer of $\mathrm{NH}_{3}$ from the pit $(p=.038)$.

(4) Under the conditions of this study, changing the slurry pit $H H$ from 0.10 to $0.90 \mathrm{~m}$ did not significantly impact $\left[\mathrm{NH}_{3}\right](p=.756)$ or $P T C$ $(p=.854)$.

\section{Disclosure statement}

No potential conflict of interest was reported by the authors.

\section{Funding}

The authors acknowledge the Institute for Agricultural and Fisheries Research (ILVO) for the financial support given to this research. 


\section{ORCID}

Luciano B. Mendes (D) http://orcid.org/0000-0003-3358-2273

\section{References}

[1] Drummond JG, Curtis SE, Simon J, Norton HW. Effects of aerial ammonia on growth and health of young pigs. J Anim Sci. 1980;50:1085-1091.

[2] ApSimon HM, Kruse M, Bell JNB. Ammonia emissions and their role in acid deposition. Atmos Environ. [Internet]. 1987 Jan [cited 2014 Dec 12]; 21:1939-1946. Available from: http://www.sciencedirect.com/science/article/pii/000 4698187901545

[3] Van der Eerden LJM. Toxicity of ammonia to plants. Agric Environ. [Internet]. 1982 Nov [cited 2015 Jan 8]; 7:223235. Available from: http://www.sciencedirect.com/science/ article/pii/0304113182900157

[4] Vellinga TV, Bannink A, Smits MCJ, Van den Pol-Van Dasselaar A, Pinxterhuis I. Intensive dairy production systems in an urban landscape, the Dutch situation. Livest Sci. [Internet]. 2011 Jul [cited 2015 Mar 23]; 139:122134. Available from: http://www.sciencedirect.com/science/ article/pii/S187114131100093X

[5] Rivas-Garcia P, Botello-Alvarez JE, Seabra JEA, da Silva Walter AC, Estrada-Baltazar A. Environmental implications of anaerobic digestion for manure management in dairy farms in Mexico: a life cycle perspective. Environ Technol. 2015;2015:1-12.

[6] Groot Koerkamp PWG, Metz JHM, Uenk GH, et al. Concentrations and emissions of ammonia in livestock buildings in Northern Europe. J Agric Eng Res. [Internet]; 1998;70:79-95. Available from: http://www.sciencedirect. com/science/article/pii/S002186349890275X

[7] Demmers TGM, Phillips VR, Short LS, et al. SE - structure and environment: validation of ventilation rate measurement methods and the ammonia emission from naturally ventilated dairy and beef buildings in the United Kingdom. J Agric Eng Res. [Internet]; 2001;79:107-116. Available from: http://www.sciencedirect.com/science/article/pii/S00 21863400906784

[8] Voorburg JH, Kroodsma W. Volatile emissions of housing systems for cattle. Livest Prod Sci. [Internet]. 1992 May [cited 2015 Mar 23]; 31:57-70. Available from: http://www.sciencedirect.com/science/article/pii/03016226 92900526

[9] Muck RE. Urease activity in bovine feces. J Dairy Sci. [Internet]. 1982 Nov [cited 2014 Dec 12]; 65:2157-2163. Available from: http://www.sciencedirect.com/science/ article/pii/S0022030282824752

[10] Aarnink AJA, Elzing A. Dynamic model for ammonia volatilization in housing with partially slatted floors, for fattening pigs. Livest Prod Sci. [Internet]. 1998 Feb [cited 2015 Jan 7];53:153-169. Available from: http://www.sciencedirect.com/science/article/pii/S0301622 69700153X

[11] Schefferle HE. The decomposition of uric acid in built up poultry litter. J Appl Microbiol. [cited 2015 Jan 7]; 2008;28:412-420. Available from: http://onlinelibrary. wiley.com/doi/10.1111/j.1365-2672.1965.tb02171.x

[12] Nielsen HB, Ahring BK. Effects of tryptone and ammonia on the biogas process in continuously stirred tank reactors treating cattle manure. Environ Technol. [cited 2015 Jan 7]; 2007;28:905-914. Available from: http:/www.ncbi.nlm.nih.gov/pubmed/17879849
[13] Bicudo JR, Goyal SM. Pathogens and manure management systems: a review. Environ Technol. [cited 2015 Jun 15]; 2003;24:115-130. Available from: http://www.tandfonline. com/doi/pdf/10.1080/09593330309385542

[14] Elzing A, Monteny GJ. Modeling and experimental determination of ammonia emission rates from a scale model dairy-cow house. Trans ASABE. [cited 2015 Jan 7]; 1997; 40:721-726. Available from: https://elibrary.asabe.org/ azdez.asp?AID $=21302 \& \mathrm{~T}=2$

[15] Monteny GJ, Schulte DD, Elzing A, Lamaker EJJ. A conceptual mechanistic model for the ammonia emissions from free stall cubicle dairy cow houses. Trans ASAE. [cited 2015 Jan 7]; 1998;41:193-201. Available from: https://elibrary.asabe.org/azdez.asp?JID $=\&$ AID $=17151$ $\& \mathrm{t}=2 \& \mathrm{v}=\& \mathrm{i}=\& \mathrm{CID}=\&$ redir $=\&$ redirType $=\&$ down $\mathrm{PDF}=\mathrm{Y}$

[16] Ni JQ, Coenegrachts J, Hendriks J. Effect of slurry on ammonia emission from a fatening pig house with partly slatted floor. Livest Prod Sci. 1999;59:25-31.

[17] Ni JQ. Mechanistic models of ammonia release from liquid manure: a review. J Agric Eng Res. [Internet]. 1999 Jan [cited 2014 Nov 25]; 72:1-17. Available from: http://www.sciencedirect.com/science/article/pii/S0021863 498903420

[18] Smits MC, Monteny G, van Duinkerken G. Effect of nutrition and management factors on ammonia emission from dairy cow herds: models and field observations. Livest Prod Sci. [Internet]. 2003 Dec [cited 2015 Feb 1]; 84:113123. Available from: http://www.sciencedirect.com/science/ article/pii/S0301622603002318

[19] Snoek DJW, Stigter JD, Ogink NWM, Groot Koerkamp PWG. Sensitivity analysis of mechanistic models for estimating ammonia emission from dairy cow urine puddles. Biosyst Eng. [Internet]; 2014;121:12-24. Available from: http://www.sciencedirect.com/science/article/pii/S1537511 01400018X

[20] Incropera FP, DeWitt DP, Bergman TL, Lavine AS. Fundamentals of heat and mass transfer. 6th ed. New York: Willey; 2006.

[21] Oenema O, Oudendag D, Velthof GL. Nutrient losses from manure management in the European Union. Livest Sci. [Internet]; 112:261-272. 2007 Dec [cited 2015 Feb 1]. Available from: http://www.sciencedirect.com/science/ article/pii/S1871141307004763

[22] Mohaibes M, Vuorinen H, Heinonen-Tanski H. Effect of temperature on microbial population and performance of an aerobic thermophilic reactor treating cattle slurry and waste food. Environ Technol. 2011 Aug [cited 2015 Jun 16];32:1223-1232. Available from: http://www. ncbi.nlm.nih.gov/pubmed/21970164

[23] Olesen JE, Sommer SG. Modelling effects of wind speed and surface cover on ammonia volatilization from stored pig slurry. Atmos Environ Part A Gen Top. [Internet]. 1993 Nov [cited 2014 Dec 12];27:2567-2574. Available from: http://www.sciencedirect.com/science/article/pii/09601686 93900303

[24] Koelliker JK, Miner JR. Desorption of ammonia from anaerobic lagoons. Trans ASAE. 1973;16:148-151.

[25] Smits MCJ, Valk H, Elzing A, Keen A. Effect of protein nutrition on ammonia emission from a cubicle house for dairy cattle. Livest Prod Sci. [Internet]. 1995 Nov [cited 2015 Mar 24];44:147-156. Available from: http://www. sciencedirect.com/science/article/pii/0301622695000686

[26] Rico C, Garcia H, Rico JL, Fernández J, Renedo J. Evolution of composition of dairy manure supernatant in a 
controlled dung pit. Environ Technol. 2009 [cited 2015 Jun 16];30:1351-1359. Available from: http://www.ncbi.nlm. nih.gov/pubmed/20088199

[27] Ye Z, Zhang G, Li B, Strom JS, Dahl PJ. Ammonia emissions affected by airflow in a model pig house: effects of ventilation rate, floor slat opening and headspace height in a manure storage pit. Trans ASAE. 2008 [cited 2015 Jun 16];51:2113-2122. Available from: http://www.prairieswine.com/pdf/39001.pdf.

[28] Ye Z, Zhang G, Seo IH, et al. Airflow characteristics at the surface of manure in a storage pit affected by ventilation rate, floor slat opening, and headspace height. Biosyst Eng. [Internet]. 2009 Sep [cited 2014 Nov 17];104:97105. Available from: http://www.sciencedirect.com/science/ article/pii/S153751100900155X

[29] Saha CK, Zhang G, Ni JQ, Ye Z. Similarity criteria for estimating gas emission from scale models. Biosyst Eng. [Internet]. 2011;108:227-236. Available from: http://www.sciencedirect.com/science/article/pii/S1537511 010002564

[30] Van Gansbeke S. Het ontwerp van melkveestallen [On the design of dairy cow barns]. [Internet]. Brussels (Belgium): Dep. Landbouw en Viss. Vlaam. Overheid [Department of Agriculture and Fisheries, Government of Flanders]; 2014 [cited 2014 Nov 17];31:1-84. Available from: http://lv.vlaanderen.be/sites/default/files/attachments/BO31_Ontwerp_melkveestallen.pdf

[31] VLM. Vlaamse Landmaatschappij [Flemish Land Agency] [Internet]. Brussels: Belgium; 2015 [cited 2014 Nov 17]; Available from: www.vlm.be

[32] Haslam RT, Hershey RL, Kean RH. Effect of gas velocity and temperature on rate of absorption. Ind Eng Chem. 1924;16:1224-1230.

[33] Court MN, Stephen RC, Waid JS. Toxicity as a cause of the inefficiency of urea as a fertilizer. I. Review. Eur J Soil Sci. 1964 [cited 2014 Nov 17];15:42-48. Available from: http://onlinelibrary.wiley.com/doi/10.1111/j.1365-2389. 1964.tb00243.x/abstract

[34] Jayaweera GR, Mikkelsen DS. Ammonia volatilization from flooded soil systems: a computer model. II. Theory and model results. Soil Sci Soc Am J. 1990 [cited 2014 Nov 17];54(5):1447-1455. Available from: https://www.soils.org/publications/sssaj/abstracts/54/5/SS 0540051447

[35] Van der Molen J, van Faassen HG, Leclerc MY, Vriesema $\mathrm{R}$, Chardon WJ. Ammonia volatilization from arable land after application of cattle slurry. 1. Field estimates. Netherlands J. Agric. Sci. 1990 [cited 2014 Nov 17];38:145-158. Available from: http://www.biometeorology.uga.edu/pubs/ vandermolen1990.pdf
[36] Ikeguchi A, Kamo M. Mass transfer of moisture and ammonia from manure and manure litter mixture in freestall housing. Trans ASABE. 1997 [cited 2014 Nov 22];40:1191-1197. Available from: https://elibrary.asabe. org/azdez.asp? JID $=\& \mathrm{AID}=21340 \& \mathrm{t}=2 \& \mathrm{v}=\& \mathrm{i}=\&$ $\mathrm{CID}=\&$ redir $=\&$ redirType $=\&$ downPDF $=\mathrm{Y}$

[37] Rong L, Nielsen PV, Zhang G. Effects of airflow and liquid temperature on ammonia mass transfer above an emission surface: experimental study on emission rate. Bioresour Technol. [Internet]. 2009 Oct [cited 2015 Jan 7];100:4654 4661. Available from: http://www.sciencedirect.com/ science/article/pii/S0960852409005148

[38] Saha CK, Zhang G, Ni J-Q. Airflow and concentration characterization and ammonia mass transfer modelling in wind tunnel studies. Biosyst Eng. [Internet]. 2010;107:328 340. Available from: http://www.sciencedirect.com/science/ article/pii/S153751101000200X

[39] Vaddella VK, Ndegwa PM, Ullman JL, Jiang A. Mass transfer coefficients of ammonia for liquid dairy manure. Atmos Environ. [Internet]. 2013 Feb [cited 2014 Dec 12];66:107113. Available from: http://www.sciencedirect.com/science/ article/pii/S1352231012007492

[40] De Paepe M. Experimental and model-based study of airflows and ammonia distributions in and around animal houses [dissertation]. Gent: Gent University; 2014

[41] Townsend AA. The structure of turbulent shear flow. 2nd ed. Cambridge: Cambridge University Press; 1976.

[42] Mendes LB, Edouard N, Ogink NWM, et al. Spatial variability of mixing ratios of ammonia and tracer gases in a naturally ventilated dairy cow barn. Biosyst Eng. [Internet] 2015 Jan [cited 2014 Dec 3];129:360-369. Available from: http://www.sciencedirect.com/science/article/pii/S1537511 014002037

[43] Ye Z, Zhang G, Li B, et al. Influence of airflow and liquid properties on the mass transfer coefficient of ammonia in aqueous solutions. Biosyst Eng. [Internet]. 2008 Jul [cited 2014 Dec 12];100:422-434. Available from: http://www.sciencedirect.com/science/article/pii/S1537511 008001414

[44] Morsing S, Strøm JS, Zhang G, Kai P. Scale model experiments to determine the effects of internal airflow and floor design on gaseous emissions from animal houses. Biosyst Eng. [Internet]. 2008 Jan [cited 2015 Feb 18];99:99104. Available from: http://www.sciencedirect.com/science/ article/pii/S1537511007002681

[45] Ye Z, Zhu S, Kai P, et al. Key factors driving ammonia emissions from a pig house slurry pit. Biosyst Eng. [Internet]. 2011 Mar [cited 2014 Nov 22];108:195-203. Available from: http://www.sciencedirect.com/science/article/pii/S15 37511010002527 